\title{
Cumulative Chemical Exposures During Pregnancy and Early Development
}

\author{
Susanna D. Mitro ${ }^{1} \cdot$ Tyiesha Johnson $^{1} \cdot$ Ami R. Zota $^{1}$
}

Published online: 4 September 2015

(C) Springer International Publishing AG 2015

\begin{abstract}
Industrial and consumer product chemicals are widely used, leading to ubiquitous human exposure to the most common classes. Because these chemicals may affect developmental milestones, exposures in pregnant women and developing fetuses are of particular interest. In this review, we discuss the prevalence of chemical exposures in pregnant women, the chemical class-specific relationships between maternal and fetal exposures, and the major sources of exposures for six chemical classes of concern: phthalates, phenols, perfluorinated compounds (PFCs), flame retardants, polychlorinated biphenyls (PCBs), and organochlorine pesticides (OCs). Additionally, we describe the current efforts to characterize cumulative exposures to synthetic chemicals during pregnancy. We conclude by highlighting gaps in the literature and discussing possible applications of the findings to reduce the prevalence of cumulative exposures during pregnancy.
\end{abstract}

This article is part of the Topical Collection on Synthetic Chemicals and Health

Ami R. Zota

azota@gwu.edu

Susanna D. Mitro

smitro@gwu.edu

Tyiesha Johnson

ttj14@gwu.edu

1 Department of Environmental and Occupational Health, Milken Institute School of Public Health, George Washington University, 950 New Hampshire Avenue NW, Suite 414,

Washington, DC 20052, USA
Keywords Cumulative exposure $\cdot$ Pregnancy $\cdot$ Phthalates · Phenols · Flame retardants · Perfluorinated compounds . Polychlorinated biphenyls · Organochlorine pesticides

\section{Introduction}

Synthetic chemicals are ubiquitous in modern society. As of 2012, more than 80,000 chemical substances are listed for use by the US Environmental Protection Agency, with about 1500 new chemicals manufactured or imported each year [1]. Approximately 3000 of these chemicals are used or imported in volumes greater than 1 million pounds/year and are found in a wide variety of consumer products, including cleaning and personal care products, building materials and home furnishings, electronics, food packaging, pharmaceuticals, and pesticides, leading to widespread human exposure [1,2•].

Pregnant women's exposures to synthetic chemicals are especially important, because many chemicals may be transferred from mother to child across the placenta and via breast milk [3•, 4]. Furthermore, synthetic chemicals may disrupt development even at low levels [5]. For the fetus and neonate, exposures to environmental toxicants may result in a wide range of adverse health consequences across the life course and potentially be transmitted to the next generation [2•].

Growing interest in the impacts of environmental chemicals on fetal growth and development, coupled with advances in analytical chemistry, has led to a substantial body of scientific literature characterizing exposures to chemicals across the maternal/fetal unit during pregnancy and early postpartum. These studies have largely relied on biomonitoring of human tissue matrices (e.g., serum, urine, and breast milk) to estimate internal exposures to a variety of contemporary and banned chemical classes. 
In this review, we will describe the prevalence and sources of chemical exposures in pregnant women, and the relationships between maternal and fetal exposures, for six chemical classes of interest: phthalates, phenols, perfluorinated compounds, flame retardants, polychlorinated biphenyls, and organochlorine pesticides (see Table 1). We will also discuss the much smaller literature attempting to characterize cumulative exposures to these six classes during pregnancy. We will conclude by highlighting gaps in the literature and discussing possible scientific and public health implications of the findings. To ensure our review is current and focused, we will concentrate on literature from North America and Europe, published in the preceding 5 years.

\section{Phthalates}

Phthalates are used for a variety of purposes: as softeners in vinyl plastics, as solvents in personal care products, and as coatings in medications, among other uses [6]. Phthalates are non-persistent chemicals in humans, with half-lives of about 12-24 h, so measured levels reflect recent exposures [7]. Younger age, greater use of cleaning products and personal care products, and a high-fat diet are associated with higher levels of phthalates in pregnant women [8-10]. Early life exposure to phthalates is associated with the development of allergic diseases, altered neurodevelopment, endocrine disruption including reduced anogenital distance in male infants [11, 12], and preterm birth [13].

Phthalate metabolites are frequently detected in the urine of pregnant women. Most measured metabolites are detected in 90-100\% of maternal urine samples during pregnancy and immediately postpartum (e.g., [8, 14, 15]). Additionally, phthalates or phthalate metabolites can cross the placental membrane. Up to 18 phthalate metabolites have been detected in neonatal urine $[16,17]$, and phthalate metabolites are also detected at low levels in cord blood and amniotic fluid [18, 19], breast milk [14], and meconium [20]. Although phthalates or their metabolites may cross the placenta, the evidence suggests that they do not accumulate in the fetus. In one study, newborns' urinary phthalate levels were generally similar to or lower than the levels found in their mothers' urine [17]. Similarly, in a second study levels of mono-(2-ethylhexyl) phthalate (MEHP) in maternal and cord blood were highly correlated, though levels in cord were slightly lower than maternal levels [20]. It is unclear whether phthalate metabolism or placental transfer varies during pregnancy. Two studies of maternal

Table 1 Summary of the detection frequency, health effects, and maternal/fetal transfer evidence for six chemical classes (phthalates, phenols, perfluorinated compounds (PFCs), flame retardants, polychlorinated biphenyls (PCBs), organochlorine pesticides (OCs))

\begin{tabular}{|c|c|c|c|c|c|c|c|}
\hline \multirow[t]{2}{*}{ Chemical } & \multicolumn{2}{|c|}{ Detection frequency ${ }^{\mathrm{a}}$} & \multirow{2}{*}{$\begin{array}{l}\text { Potential health effects from } \\
\text { early developmental exposures }\end{array}$} & \multicolumn{2}{|c|}{ Evidence for transfer } & \multirow{2}{*}{$\begin{array}{l}\text { Accumulate in } \\
\text { fetus? }\end{array}$} & \multirow[t]{2}{*}{ Persistent? } \\
\hline & Maternal & Fetal/neonatal & & Placental & Breastfeeding & & \\
\hline Phthalates & $\begin{array}{l}90-100 \% \text { in } \\
\text { urine }\end{array}$ & $90-100 \%$ in urine & $\begin{array}{l}\text { Allergic disease; altered } \\
\text { cognitive and behavioral } \\
\text { development; altered male } \\
\text { reproductive tract } \\
\text { development; endocrine } \\
\text { disruption; preterm delivery }\end{array}$ & Yes & Yes & No & No \\
\hline Phenols & $\begin{array}{l}80-100 \% \text { in } \\
\text { urine }\end{array}$ & $40-60 \%$ in urine & $\begin{array}{l}\text { Asthma; altered cognitive and } \\
\text { behavioral development; } \\
\text { cardiometabolic disorders; } \\
\text { endocrine disruption }\end{array}$ & Yes & Yes & No & No \\
\hline PFCs & $\begin{array}{l}90-100 \% \text { in } \\
\text { serum }\end{array}$ & $\begin{array}{l}90-100 \% \text { in cord } \\
\text { serum }\end{array}$ & $\begin{array}{l}\text { Endocrine disruption; reduced } \\
\text { fetal growth }\end{array}$ & Yes & Yes & Yes & Yes \\
\hline $\begin{array}{l}\text { Flame } \\
\quad \text { retardants }\end{array}$ & $\begin{array}{l}90-100 \% \text { in } \\
\text { serum }\end{array}$ & $\begin{array}{l}70-100 \% \text { in cord } \\
\text { serum }\end{array}$ & $\begin{array}{l}\text { Altered cognitive and } \\
\text { behavioral development; } \\
\text { thyroid hormone disruption }\end{array}$ & Yes & Yes & Yes & Yes \\
\hline PCBs & $\begin{array}{l}80-100 \% \text { in } \\
\text { serum }\end{array}$ & $\begin{array}{l}90-100 \% \text { in cord } \\
\text { serum }\end{array}$ & $\begin{array}{l}\text { Altered cognitive and } \\
\text { behavioral development; } \\
\text { thyroid hormone disruption; } \\
\text { reduced fetal growth }\end{array}$ & Yes & Yes & Yes & Yes \\
\hline OCs & $\begin{array}{l}90-100 \% \text { in } \\
\text { serum }\end{array}$ & $\begin{array}{l}90-100 \% \text { in cord } \\
\text { serum }\end{array}$ & $\begin{array}{l}\text { Altered cognitive and } \\
\text { behavioral development; } \\
\text { endocrine disruption; } \\
\text { immune suppression }\end{array}$ & Yes & Yes & Yes & Yes \\
\hline
\end{tabular}

\footnotetext{
${ }^{a}$ Detection frequency is a general estimate, based on the literature, of the percent of individuals in a North American or European population having detectable levels of at least two congeners from a given class

${ }^{\mathrm{b}}$ Class is recorded as accumulating in the fetus if there is at least some evidence that fetal transfer is occurring at a rate greater than maternal exposure, e.g., (1) fetal levels exceed maternal levels or (2) maternal levels decrease during pregnancy or breastfeeding
} 
urinary phthalate metabolites reported either no differences by gestational age [8] or results that varied by metabolite [21]. However, two other studies in maternal urine and amniotic fluid suggested that some phthalate metabolite levels may increase with gestational week $[18,22]$.

\section{Phenols}

Phenols are used in a variety of consumer products, including in the lining of food cans, in plastic bottles, in dental sealants, as antimicrobials, and as preservatives [6, 23]. Phenols, including bisphenol A (BPA), triclosan, and parabens, are nonpersistent chemicals that are rapidly metabolized and eliminated, with half-lives in the human body between 6 and $30 \mathrm{~h}$ [24]. Higher levels of phenols in pregnant women are associated with use of mouthwash and cosmetics, as well as higher body mass index (BMI) and higher education level [23, 25, 26]. Higher prenatal BPA has been associated with younger age, lower socioeconomic status, black race, and consumption of canned vegetables [27]. Early-life BPA exposure is associated with impaired neurodevelopment, endocrine disruption, childhood asthma, and possibly cardiometabolic disorders $[12,28]$. Other phenols, such as triclosan and parabens, may also act as endocrine disrupters but their human health effects are less well characterized [29, 30].

BPA is measurable in maternal urine throughout pregnancy and postpartum, frequently in $80-100 \%$ of samples (e.g., [23, $25,31 \cdot 32,33])$ and is also detected in maternal serum [34, 35] and breast milk $[31 \bullet, 32]$. Triclosan is also frequently detected in maternal urine, serum, and breast milk [23, 25, 31 • 32, 33]. Methyl and propyl parabens are detected in nearly $100 \%$ of maternal urine and breast milk, while butyl and ethyl parabens are detected less frequently $[23,25,32,33]$. Detection of BPA and triclosan in neonatal urine [31•], cord blood [34-36], placental tissue [37, 38], amniotic fluid [33, 39], meconium [31•] and fetal liver [38] indicates that phenols are able to cross the placenta throughout pregnancy. Triclosan levels in infant meconium are highly correlated with levels in their mothers' urine [31•]. BPA levels in amniotic fluid are weakly correlated with maternal urinary levels [33], and BPA levels in the placenta are correlated with fetal liver levels [38]. However, phenols do not seem to accumulate in the fetus. BPA is typically found at much lower levels in amniotic fluid than in maternal urine [33], and at much lower levels in cord serum than maternal serum [35-37, 40] (with exceptions [34]).

\section{Perfluorinated Chemicals}

Perfluorinated compounds (PFCs) are persistent industrial chemicals used to impart water and stain resistance to consumer products [41]. PFCs preferentially bind to proteins such as albumin, and due to their highly stable chemical structure, they bioaccumulate and remain in the human body (and the environment) long after exposure [42]. In pregnant women, parity and previous breastfeeding duration are inversely associated with PFC level, while age and living in an industrialized environment are positively associated; mixed results have been found for BMI, smoking, and diet [43-48]. Developmental exposure to PFCs is associated with reduced fetal growth [41] and possible endocrine disruption in females [49], but few other neonatal health effects have been strongly linked to PFC exposure.

PFCs, particularly perfluorooctane sulfonate (PFOS), perfluorooctanesulfonic acid (PFOA), perfluorononanoic acid (PFNA), perfluorodecanoic acid (PFDA), and perfluorohexane sulfonate (PFHxS), are detected in the serum of nearly $100 \%$ of pregnant women (e.g., [43, 50, 51]); longer-chain compounds are also frequently detected, though sometimes at lower levels $[43,47,50,52]$. PFCs have also been detected in breast milk [51, 53-55]. Widespread detection of PFCs in cord blood [47, $56]$, amniotic fluid $[18,52]$, and placental tissue $[57,58]$ indicates that PFCs can cross the placenta. The degree of placental transfer varies by the biochemical properties of each congener. Short-chain PFCs and PFCs that bind to fatty blood proteins are the most readily transferred from maternal serum to cord serum $[50,59,60]$. Depending on the congener, maternal PFC levels may be one to six times higher than cord levels [3•, 45, 47, 50, 59]. Although fetal levels remain lower than maternal levels in most cases, placental transfer may occur in excess of maternal exposure. PFC levels in maternal serum decrease more than $10 \%$ during pregnancy, with some congeners decreasing more than a third from pre-pregnancy levels [43, 46, 47, 61]. These trends are likely due to both dilution from increased blood volume during pregnancy and placental transfer [47, 61].

Breastfeeding is additionally thought to be a major source of neonatal PFC exposure. Lipid-adjusted PFC levels in breast milk may be higher than maternal serum levels [57]. Maternal serum [43, 51] and breast milk [62] PFC levels decrease continuously with breastfeeding, and women who have previously breastfed have lower serum PFC levels [46, 54]. Additionally, longer breastfeeding and exclusive breastfeeding are associated with increased infant serum PFC levels [4].

\section{Flame Retardants}

Flame retardants are used in upholstered furniture, electronics, and textile products [6]. Most polybrominated diphenyl ether (PBDE) flame retardants are no longer used in the USA, and replacement flame retardants (RFRs) have been developed as alternatives. However, because flame retardants are lipophilic persistent chemicals, with half-lives between a few months to over 10 years in adult human adipose tissue, PBDEs as well as RFRs are still detected by biomonitoring [63]. Greater number of electronic appliances and pieces of stuffed furniture at home, non-Hispanic ethnicity, and longer time living in the USA are associated with higher PBDEs in pregnant women 
[64-67]; low income pregnant women in California are very highly exposed, likely due to California furniture flammability standards [64]. PBDE exposure has been associated with reproductive toxicity [12], thyroid hormone disruption in pregnant women and newborns, and poorer mental and psychomotor development including decrements in IQ and poorer attention in children $[68,69]$, while the health effects of RFRs are not yet fully known.

PBDEs, especially BDE-47 and BDE-153, followed by BDE-28, BDE-99, BDE-100, and BDE-209, are detected in the serum of nearly all pregnant women (e.g., [64, 70-72]). PBDEs are also frequently detected in breast milk $[65,73]$. RFRs have also been measured in maternal serum and breast milk [67, 74-76], and RFR metabolites are measurable in maternal urine [77]. Flame retardants are able to cross the placenta throughout pregnancy $[72,78]$, though maternal levels do not decrease [77, 78]. PBDEs have been measured in cord serum [71, 73], placenta [72, 79], amniotic fluid [80], and colostrum [81]. RFRs have been measured in cord serum and the placenta [76]. PBDE metabolites (OH-PBDEs) are also found, at much lower levels, in both maternal and fetal matrices $[55,64,70,82 \cdot]$. The extent of placental transfer and possible accumulation varies by chemical (and is affected by lipid adjustment) [71]. Some PBDEs have consistent transfer patterns: BDE-153 is higher in maternal serum, BDE-99 is higher in cord serum, BDE-100 is similar across matrices $[70,71,73]$, and OH-PBDEs may be higher in cord serum $[70,83]$. However, others, such as BDE-47 and BDE-28, show a less-consistent pattern $[70,71,73,74,81]$. Similarly, some RFRs are higher in maternal serum, but others are higher in cord serum [74, 76]. Several studies suggest that highly brominated PBDEs cross the placenta more readily than lower brominated PBDEs [73, 84], but one systematic review did not support that pattern $[3 \bullet]$.

\section{PCBs}

Polychlorinated biphenyls (PCBs) are industrial chemicals that were once widely used as lubricants and coolants, and now persist in the environment despite being banned [85]. PCBs are highly persistent, lipophilic chemicals that accumulate in humans and the environment and have half-lives of 1020 years or longer in adipose tissue [86]. Because PCBs bioaccumulate, maternal levels are associated with age and birth year [87-89], and women who eat high quantities of fatty fish and game, such as Inuit and northern Norwegian mothers, are highly exposed $[90,91]$. PCBs are reproductive toxicants [12], and developmental exposure to PCBs may adversely affect thyroid hormones, child neurodevelopment, and birth weight $[69,92]$.

PCB-138, PCB-153, PCB-170, and PCB-180 are the most frequently detected congeners, typically detected in $80-100 \%$ of maternal serum samples [88, 93-97] as well as colostrum and breast milk [97-102]. PCBs are able to cross the placenta and are widely detected in cord blood [103-105], placenta [106-108], meconium [94], and amniotic fluid [109, 110]. Hydroxylated PCB metabolites (OH-PCBs) are also detected in multiple matrices at lower levels than the parent PCBs [94, 106]. Nearly all PCBs are found in higher levels in maternal than cord serum [103, 111-113], with only a few congeners found at similar levels across both or higher in cord [103, 113, 114]. Two recent studies suggest that lower chlorinated PCB congeners are more readily transferred than highly chlorinated ones [111, 112], though other studies, including an earlier systematic review, did not support that pattern [3•, 103, 114]. Placental transfer may decrease as congener molecular weight increases [111] or as congener lipophilicity increases [103]. Parity also may contribute to inter-individual differences in placental transfer: one study reported a higher rate of placental transfer of PCB-157 in primiparous women, though placental transfer rates for other organochlorines were higher in multiparas [114]. Although most studies find that lipid-adjusted PCB levels decrease during pregnancy, the effect is likely due to dilution as blood volume increases [115].

After birth, PCBs are likely transferred to the neonate during breastfeeding. PCB levels are somewhat higher in colostrum than in mature milk [98], and multiparous women have lower serum PCB levels [116]. Two studies found that PCB levels in breast milk significantly decrease over the course of breastfeeding $[62,99]$, though a third found no decline in serum or milk levels [97].

\section{Organochlorine Pesticides}

Organochlorine pesticides (OCs) are persistent lipophilic chemicals that accumulate in adipose tissue [117]. Therefore, despite being banned decades ago, OCs persist in the environment and human tissue [110]. Maternal OC levels are closely associated with recent exposure to pesticides; women who live in Latin America and other regions that use OCs for pest control or agriculture have comparatively higher OC levels [104, 118, 119]. OC exposure may be associated with adverse psychomotor and attention development, immune suppression, and endocrine disruption, among other effects [12, 69, 96, 120].

Dichlorodiphenyldichloroethylene (DDE), hexachlorobenzene (HCB), and trans-nonachlor are typically detected in over $90 \%$ of samples across matrices, including maternal serum [88, 93, 95, 105], breast milk [97, 100, 101, 121]. Oxychlordane and $\beta$-hexachlorocyclohexane $(\beta-\mathrm{HCH})$ are detected less frequently, but still often present in over half of maternal samples [93, 97, 105]. OCs are able to cross the placenta and are detected in cord serum [104, 122, 123], meconium [94], placenta [124] and amniotic fluid [109, 110]. Using wet weights, OC levels are higher in maternal than cord blood, though the difference is slight for some compounds [113, 114, 125]. Using lipid-adjusted measures, OC levels 
are typically slightly higher in cord than maternal serum, though the levels are not different enough to imply fetal accumulation $[114,125,126]$. Additionally, levels of DDE and dichlorodiphenyltrichloroethane (DDT) in maternal serum do not differ across trimesters of pregnancy [116, 127, 128]. Breast milk may also be a vehicle of transfer for OCs. OC levels are higher in breast milk than maternal serum [97, 129], and levels in breast milk fat decline during the first month postpartum [130]. However, it is unclear whether maternal serum OC levels change during breastfeeding [97, 131].

\section{Cumulative Exposures}

In addition to the extensive literature measuring single chemical classes in the maternal/fetal unit, some recent studies have measured cumulative exposures to multiple chemical classes. Of studies measuring multiple chemicals, most have measured the chemicals of interest in a single matrix (e.g., maternal urine or maternal serum; Table 2). Certain classes are frequently measured together, for example, non-persistent phthalates and phenols are often measured in urine, whereas persistent chemicals such as PFCs, flame retardants, OCs, and PCBs are commonly measured in serum or breast milk. However, few papers have attempted to capture a complete picture across classes and matrices.

Cumulative exposure studies measuring only nonpersistent chemicals typically report that around a third to a half of the measured chemicals is detected in all participants. One study measuring 26 phenol and phthalate metabolites found a median of 16 chemicals in each pregnant woman, with more than half the chemicals detected in the majority of women [132]. Another two studies, both measuring 20 phenol and phthalate metabolites, reported that every woman had detectable levels of seven [133] or eight of the chemicals [134], respectively, while one to two additional chemicals in each study were detected in all but a few women.

Cumulative exposure studies measuring only persistent chemicals have also reported widespread simultaneous exposure to many chemicals. Two studies of placental tissue both reported universal detection of about $20-25 \%$ of measured PBDEs and organochlorine compounds [107, 135•]. Studies measuring maternal serum reported simultaneous detection of between $2-5$ chemicals in all samples, representing between 11 and $57 \%$ of chemicals measured $[82 \bullet, 95,118,135 \bullet$, 136-138], although fewer chemicals were detected in all cord blood samples [135•, 139]. Similarly, in breast milk, studies reported the simultaneous detection of at least $20 \%$ of the measured chemicals in every woman's milk, with most studies detecting around a third of the measured chemicals in all samples $[100,101,140,141]$. One study detected fully half the chemicals it measured in every breast milk sample (16/31 chemicals [97]).
Several studies measuring total cumulative exposure detect a multitude of chemicals from many classes, including both persistent and non-persistent chemicals. In one US study measuring 52 total chemicals, including phthalates, BPA, PFCs, OCs, PCBs, and PBDEs, at least 21 chemicals were detected in every woman; the median number of chemicals measured was 44 , and all 52 chemicals were measured in some women [142•]. In a nationally representative US study, eight chemicals were detected in every pregnant woman including three PCBs, two OCs, one PBDE, one phenol, and two phthalate metabolites; 15 chemicals were detected in at least $99 \%$ of women [2•]. Finally, a Swiss study measuring 39 phenols, phthalate metabolites, PCBs, PBDEs, and pesticides in breast milk found 15 of the chemicals in every sample [121].

Despite widespread exposure to multiple classes of chemicals, chemical levels between classes are not well correlated. PCB and PBDE levels tend to be poorly correlated in maternal serum, breast milk, and placental tissue $[82 \cdot, 107$, $137,138,143,144]$. Phthalates and phenols are weakly correlated in some studies [134, 145], and more strongly correlated in others $[132,146]$. Because exposure to high levels of one class does not appear to be consistently predictive of exposure levels within other classes, modeling (or predicting) cumulative exposures is likely to be complex.

\section{Discussion}

Pregnant women are exposed to a large number of synthetic chemicals, including both banned and contemporary contaminants, and existing data form only a partial picture of the prevalence of cumulative exposures. Several chemicals from each class are routinely detected at close to $100 \%$ across studies, suggesting that those chemicals are likely present in all pregnant women or fetuses, even when not explicitly measured. However, few studies with data on multiple contaminants in pregnancy cohorts have conducted cumulative impacts analyses.

Cumulative exposure assessment could be used to understand interactions between chemical classes on a particular health outcome of interest, and to control potential confounding and isolate the effects of a single class of compounds. Individually, many synthetic chemicals have been associated with similar adverse health endpoints, such as altered hormonal action in both the pregnant woman and fetus, and altered behavioral and cognitive development in children [11, 28, 69] (Table 1). Because pregnant women and fetuses are cumulatively exposed to multiple chemicals, these exposures may interact with one another, amplifying health effects. Indeed, the National Academy of Sciences recently recommended that risk assessment of multiple chemicals expand to account for the possibility of compounded effects on the outcomes of concern [147]. 
Table 2 A selection of recent cumulative exposure studies from populations in North America and Europe, including exposures to six chemical classes (phthalates, phenols, perfluorinated compounds (PFCs), flame retardants, polychlorinated biphenyls (PCBs), organochlorine pesticides (OCs))

\begin{tabular}{|c|c|c|c|c|c|c|c|c|}
\hline \multirow[t]{2}{*}{ Study } & \multirow{2}{*}{$\begin{array}{l}\text { Sample } \\
\text { size (n) }\end{array}$} & \multirow[t]{2}{*}{ Location } & \multirow[t]{2}{*}{ Years } & \multirow[t]{2}{*}{ Matrix $^{a}$} & \multicolumn{4}{|l|}{ Classes measured } \\
\hline & & & & & Phthalates Phenols & PFCs & $\begin{array}{l}\text { Flame } \\
\text { retardants }\end{array}$ & PCBs and $\mathrm{OCs}$ \\
\hline
\end{tabular}

Maternal serum (MS)

Abdelouahab et al. [136]

Adlard et al. [118]

$\begin{array}{llll}380 & \text { Canada } & 2007-2008 & \text { MS } \\ 363 & \text { Canada, Mexico } & 2005-2007 & \text { MS } \\ 48 & \text { USA } & 2003 & \text { MS } \\ 150 & \text { Finland } & 1991-2000 & \text { MS } \\ 62 & \text { Netherlands } & 2001-2002 & \text { MS } \\ 1117 & \text { Greece } & 2007-2008 & \text { MS } \\ 100 & \text { Denmark } & 2011 & \text { MS } \\ 61 & \text { USA } & 2008-2012 & \text { MS }\end{array}$

Carmichael et al. [137] 48

Cheslack-Postava et al. [88] 150

Roze et al. [151]

Vafeiadi et al. [95]

Vorkamp et al. [138]

61

USA

2008-2012 MS

Maternal urine (MU)

Arbuckle et al. [152]

$\begin{array}{llllll}2000 & \text { Canada } & 2008-2011 & \text { MU } & \text { x } & \text { x } \\ 137 & \text { USA } & 2004-2009 & \text { MU } & \text { x } & \text { x } \\ 177 & \text { USA } & 2005-2011 & \text { MU } & \text { x } & \text { x } \\ 120 & \text { Spain } & 2004-2008 & \text { MU } & \text { x } & \text { x } \\ 200 & \text { Denmark } & 2011 & \text { MU } & \text { x } & \text { x } \\ 107 & \text { Mexico } & 1994-2004 & \text { MU } & \text { x } & \text { x } \\ 375 & \text { USA } & 1999-2006 & \text { MU } & \text { x } & \text { x } \\ 191,287 & \text { France } & 2002-2006 & \text { MU } & \text { x } & \text { x } \\ 116 & \text { Mexico } & 1997-2004 & \text { MU } & \text { x } & \text { x } \\ 72 & \text { USA } & \text { Not listed } & \text { MU } & \text { x } & \text { x }\end{array}$

Breast milk (BM)

13 Italy 2005-2007 BM

84 Belgium 2009-2010 BM

Gómara et al. [159]

9

Hernik et al. [100]

Belgium

$2005 \quad$ BM

28 Poland

2002-2005 BM

LaKind et al. [97]

10

USA

2004-2005 BM

Lankova et al. [55]

50

Lignell et al. [140]

Czech Republic

2010

$\mathrm{BM}$

Sweden

1996-2006 BM

Park et al. [143]

Pratt et al. [160]

Raab et al. [101]

82

USA

2003-2005 BM

109

2010

BM

516 Germany 2007-2008 BM

Schlumpf et al. [121]

Schuhmacher et al. [144]

Thomsen et al. [62]

Switzerland

2004-2006 BM

Cord serum (CS)

Arbuckle et al. [139]

70

Spain

2007

BM

Norway 2001-2009 BM

Chevalier et al. [19]

Canada

2005-2008 CS

180 France 2002-2005 CS

Vizcaino et al. [161]

265 Spain

1997-1998 CS

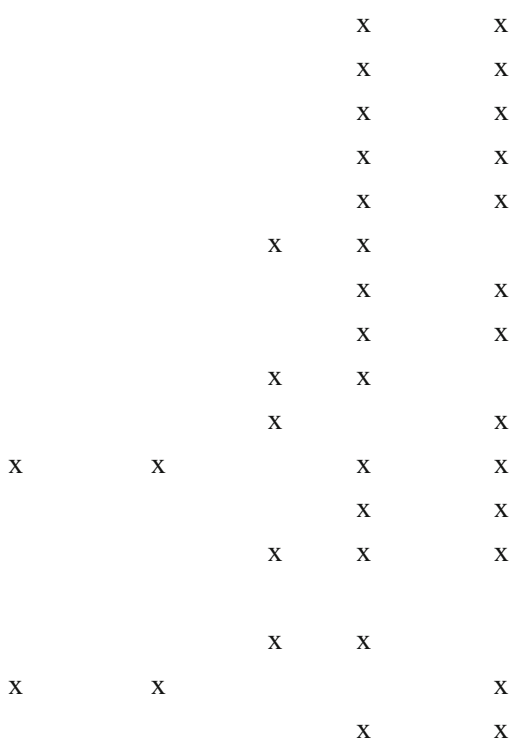

Placenta $(\mathrm{P})$ and amniotic fluid (AF)

Leino et al. [107]

130

Finland

2004-2005 P

Nanes et al. [162]

$42 \quad$ USA

Jensen et al. [18]

300

Denmark

Not listed $\mathrm{P}$

Multiple matrices

1980-1996 AF

$175 \quad$ USA

2003-2006 MU, MS

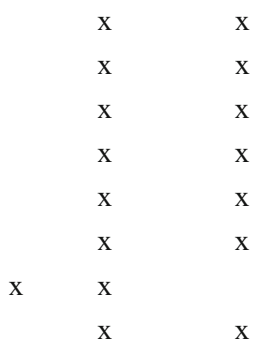

Braun et al. [142•] 
Table 2 (continued)

\begin{tabular}{|c|c|c|c|c|c|c|c|c|c|}
\hline \multirow[t]{2}{*}{ Study } & \multirow{2}{*}{$\begin{array}{l}\text { Sample } \\
\text { size (n) }\end{array}$} & \multirow[t]{2}{*}{ Location } & \multirow[t]{2}{*}{ Years } & \multirow[t]{2}{*}{ Matrix $^{a}$} & \multicolumn{5}{|c|}{ Classes measured } \\
\hline & & & & & Phthalates & Phenols & PFCs & $\begin{array}{l}\text { Flame } \\
\text { retardants }\end{array}$ & PCBs and OCs \\
\hline Brucker-Davis et al. [163] & 69,84 & France & $2002-2005$ & $\mathrm{BM}, \mathrm{CS}$ & $\mathrm{x}$ & $\mathrm{x}$ & & & $\mathrm{x}$ \\
\hline de Cock et al. [56] & 83 & Netherlands & 2011-2013 & $\mathrm{CS}, \mathrm{BM}$ & $\mathrm{x}$ & & $\mathrm{x}$ & & $\mathrm{x}$ \\
\hline Doucet et al. [164] & 52,60 & Canada & 1998-2006 & $\mathrm{P}$, fetal liver & & & & $\mathrm{x}$ & $\mathrm{x}$ \\
\hline Needham et al. [57] & 15 & Faroe Islands & 2000 & MS, BM, CS, P & & & $\mathrm{x}$ & & $\mathrm{x}$ \\
\hline Porpora et al. [165] & 38 & Italy & 2008-2009 & MS, CS & & & $\mathrm{x}$ & & $\mathrm{x}$ \\
\hline Vizcaino et al. [135•] & 308,50 & Spain & 2004-2008 & $\mathrm{MS}, \mathrm{CS}, \mathrm{P}$ & & & & $\mathrm{x}$ & $\mathrm{x}$ \\
\hline Woodruff et al. [2•] & 268 & USA & 2003-2004 & MU, MS & $\mathrm{x}$ & $\mathrm{x}$ & $\mathrm{x}$ & $\mathrm{x}$ & $\mathrm{x}$ \\
\hline
\end{tabular}

${ }^{\text {a }}$ Matrix abbreviations: $M S$ maternal serum, $M U$ maternal urine, $B M$ breast milk, $C S$ cord serum, $P$ placenta, $A F$ amniotic fluid

Another important extension of cumulative exposure assessment is exposure source reduction, both through changes in individual behavior and changes in policy to protect the population on a broader scale. Because the chemical classes described largely come from different sources, small changes in individual behavior are unlikely to reduce overall exposures. However, given the prevalence of phthalates, phenols, flame retardants, and PFCs in some household items, personal care products, and certain foods, pregnant women may consider reducing their exposure to those sources where possible.

Because many of these chemicals are produced and used in high volumes, policy changes may reduce exposures more effectively than individual behavioral changes. For example, the phase out of PBDE flame retardants in the USA and Europe has led to lower exposures in both breast milk [148] and maternal serum levels during pregnancy [82•]. However, in response to the phase out, the chemical industry introduced replacement chemicals, often very similar in structure and with equal or uncharacterized toxicity; these substitutes were soon measured in pregnant women's bodies [67, 75]. Therefore, a meaningful reduction in cumulative chemical exposures will likely entail chemical policy reform that requires more adequate assessment of health and safety concerns before market introduction, as well as a reduction in the overall use of synthetic chemicals in commerce.

Our understanding of chemical exposure during preconception and early- to mid-gestation, as well as longitudinal exposure levels, is somewhat limited by access to relevant study populations and the necessary biological matrices for chemical analysis. For example, although cord blood can provide information about fetal exposure at birth, it may not accurately reflect fetal exposures during early gestation, which may also have profound developmental effects. Additionally, neonatal urine and meconium provide metabolites, rather than parent compounds, for analysis. It can be difficult to determine whether these metabolites resulted from placental transfer or were created in the fetus directly, and in cases where metabolites are not specific to a parent compound, it may be unclear which parent compound preceded the metabolite. In some cases, the metabolite itself may be found in the environment (e.g., [149]). Finally, amniotic fluid has been used to gather data on gestational exposure, but the relationship between amniotic fluid levels and internal fetal levels is unknown, and amniotic fluid is often contaminated with maternal blood [150]. Fetal exposures throughout pregnancy might be estimated from maternal levels using known placental transfer rates, though some unanswered questions-e.g., whether the transfer rate varies during pregnancy, why certain chemicals are transferred more than others, and whether metabolites are more readily transferred than parent chemicalscurrently limit interpretation of maternal levels. Therefore, measuring cumulative exposures during pregnancy and early development may require sequential measurements of multiple matrices beginning in preconception and extending through postpartum.

\section{Conclusions}

Although a substantial number of recent studies have collected data on environmental exposures during pregnancy, few have adequately characterized cumulative exposures and their consequent effects on the developing fetus. Future research should focus on characterizing cumulative maternal and fetal exposure from preconception to postpartum and investigating possible additive or multiplicative clinical effects of multiple cumulative exposures using appropriate statistical tools. Moreover, educational materials on chemical exposures should focus on modifiable risk factors, such as diet, that are associated with multiple classes of chemicals, in attempt to reduce the cumulative chemical exposure load currently experienced by pregnant women. Because synthetic chemicals are now global contaminants, it is increasingly important to create opportunities for environmental health prevention through 
understanding and ultimately reducing cumulative exposures during pregnancy and early development.

Acknowledgment This work was supported by the National Institute of Environmental Health Sciences (R00ES019881).

\section{Compliance with Ethical Guidelines}

Conflict of Interest Susanna D. Mitro, Tyiesha Johnson, and Ami R. Zota declare that they have no conflict of interest.

Human and Animal Rights and Informed Consent This article does not contain any studies with human or animal subjects performed by any of the authors.

\section{References}

Papers of particular interest, published recently, have been highlighted as:

- Of importance

1. US Environmental Protection Agency. Overview: Office of Pollution Prevention and Toxics Programs. 2007. Available at: http://www.epa.gov/oppt/pubs/oppt101c2.pdf.

2. Woodruff TJ, Zota AR, Schwartz JM. Environmental chemicals in pregnant women in the United States: NHANES 2003-2004. Environ Health Perspect. 2011;119:878-85. This paper was among the first to attempt to quanitfy cumulative exposures to multiple chemicals in pregnant women using a nationally representative sample of pregnant women in the US.

3. Aylward LL, Hays SM, Kirman CR, et al. Relationships of chemical concentrations in maternal and cord blood: a review of available data. J Toxicol Environ Heal B. 2014;17:175-203. This systematic review comprehensively assesses the placental transfer ratios of a number of synthetic chemicals and metals.

4. Mondal D, Lopez-Espinosa MJ, Armstrong B, et al. Relationships of perfluorooctanoate and perfluorooctane sulfonate serum concentrations between mother-child pairs in a population with perfluorooctanoate exposure from drinking water. Environ Health Perspect. 2012;120:752-7.

5. Grandjean P, Landrigan PJ. Neurobehavioural effects of developmental toxicity. Lancet Neurol. 2014;13:330-8.

6. Meeker JD, Sathyanarayana S, Swan SH. Phthalates and other additives in plastics: human exposure and associated health outcomes. Philos Trans R Soc B Biol Sci. 2009;364:2097-113.

7. Hoppin JA, Brock JW, Davis BJ, et al. Reproducibility of urinary phthalate metabolites in first morning urine samples. Environ Health Perspect. 2002;110:515-8.

8. Cantonwine DE, Cordero JF, Rivera-Gonzalez LO, et al. Urinary phthalate metabolite concentrations among pregnant women in northern Puerto Rico: distribution, temporal variability, and predictors. Environ Int. 2014;62:1-11.

9. Buckley JP, Palmieri RT, Matuszewski JM, et al. Consumer product exposures associated with urinary phthalate levels in pregnant women. J Expo Sci Environ Epid. 2012;22:468-75.

10. Serrano SE, Karr CJ, Seixas NS, et al. Dietary phthalate exposure in pregnant women and the impact of consumer practices. Int $\mathrm{J}$ Environ Res Public Health. 2014;11:6193-215.

11. Braun JM, Sathyanarayana S, Hauser R. Phthalate exposure and children's health. Curr Opin Pediatr. 2013;25:247-54.
12. State of California Environmental Protection Agency. Office of Environmental Health Hazard Assessment. Safe Drinking Water and Toxic Enforcement Act of 1986: Chemicals known to the state to cause cancer or reproductive toxicity. Version June 19, 2015.

13. Ferguson KK, McElrath TF, Meeker JD. Environmental phthalate exposure and preterm birth. JAMA Pediatr. 2014;168:61-7.

14. Hines EP, Calafat AM, Silva MJ, et al. Concentrations of phthalate metabolites in milk, urine, saliva, and serum of lactating North Carolina women. Environ Health Perspect. 2009;117:86-92.

15. Swan SH, Sathyanarayana S, Barrett ES, et al. First trimester phthalate exposure and anogenital distance in newborns. Hum Reprod. 2015;30:963-72.

16. Frederiksen H, Kuiri-Hanninen T, Main KM, et al. A longitudinal study of urinary phthalate excretion in 58 full-term and 67 preterm infants from birth through 14 months. Environ Health Perspect. 2014;122:998-1005.

17. Enke U, Schleussner E, P lmke C, et al. Phthalate exposure in pregnant women and newborns - the urinary metabolite excretion pattern differs distinctly. Int J Hyg Environ Heal. 2013;216:73542.

18. Jensen MS, Norgaard-Pedersen B, Toft G, et al. Phthalates and perfluorooctanesulfonic acid in human amniotic fluid: temporal trends and timing of amniocentesis in pregnancy. Environ Health Perspect. 2012;120:897-903.

19. Chevalier N, Brucker-Davis F, Lahlou N, et al. A negative correlation between insulin-like peptide 3 and bisphenol $\mathrm{A}$ in human cord blood suggests an effect of endocrine disruptors on testicular descent during fetal development. Hum Reprod. 2015;30:447-53.

20. Li L-X, Chen L, Men X-Z, et al. Exposure levels of environmental endocrine disruptors in mother-newborn pairs in China and their placental transfer characteristics. PLoS ONE. 2013;8, e62526.

21. Ferguson KK, McElrath TF, Ko YA, et al. Variability in urinary phthalate metabolite levels across pregnancy and sensitive windows of exposure for the risk of preterm birth. Environ Int. 2014;70:118-24.

22. Irvin EA, Calafat AM, Silva MJ, et al. An estimate of phthalate exposure among pregnant women living in Trujillo. Peru Chem. 2010;80:1301-7.

23. Meeker JD, Cantonwine DE, Rivera-Gonzalez LO, et al. Distribution, variability, and predictors of urinary concentrations of phenols and parabens among pregnant women in Puerto Rico. Environ Sci Technol. 2013;47:3439-47.

24. Larsson K, Bjorklund KL, Palm B, et al. Exposure determinants of phthalates, parabens, bisphenol A and triclosan in Swedish mothers and their children. Environ Int. 2014;73:323-33.

25. Mortensen ME, Calafat AM, Ye X, et al. Urinary concentrations of environmental phenols in pregnant women in a pilot study of the National Children's Study. Environ Res. 2014;129:32-8.

26. Arbuckle TE, Marro L, Davis K, et al. Exposure to free and conjugated forms of bisphenol A and triclosan among pregnant women in the MIREC cohort. Environ Health Perspect. 2015;123:27784.

27. Braun JM, Lanphear BP, Calafat AM, et al. Early-life bisphenol A exposure and child body mass index: a prospective cohort study. Environ Health Perspect. 2014;122:1239-45.

28. Rochester JR. Bisphenol A, and human health: a review of the literature. Reprod Toxicol. 2013;42:132-55.

29. Witorsch RJ. Critical analysis of endocrine disruptive activity of triclosan and its relevance to human exposure through the use of personal care products. Cr Rev Toxicol. 2014;44:535-55.

30. Karpuzoglu E, Holladay SD, Gogal RM. Parabens: potential impact of low-affinity estrogen receptor binding chemicals on human health. J Tox Environ Heal B. 2013;16:321-35.

31. Arbuckle TE, Weiss L, Fisher M, et al. Maternal and infant exposure to environmental phenols as measured in multiple biological matrices. Sci Total Environ. 2015;508:575-84. This paper 
measured phenols in multiple matrices, including repeated measures of maternal urine throughout pregnancy, which produced detailed data on maternal and fetal/neonatal levels.

32. Hines EP, Mendola P, von Ehrenstein OS, et al. Concentrations of environmental phenols and parabens in milk, urine and serum of lactating North Carolina women. Reprod Toxicol. 2015;54:120-8.

33. Philippat C, Wolff MS, Calafat AM, et al. Prenatal exposure to environmental phenols: concentrations in amniotic fluid and variability in urinary concentrations during pregnancy. Environ Health Perspect. 2013;121:1225-31.

34. Aris A. Estimation of bisphenol A (BPA) concentrations in pregnant women, fetuses and nonpregnant women in Eastern Townships of Canada. Reprod Toxicol. 2014;45:8-13.

35. Unal ER, Lynn T, Neidich J, et al. Racial disparity in maternal and fetal-cord bisphenol A concentrations. J Perinatol. 2012;32:844 50 .

36. Zhang T, Sun H, Kannan K. Blood and urinary bisphenol A concentrations in children, adults, and pregnant women from China: partitioning between blood and urine and maternal and fetal cord blood. Environ Sci Technol. 2013;47:4686-94.

37. Leclerc F, Dubois MF, Aris A. Maternal, placental and fetal exposure to bisphenol A in women with and without preeclampsia. Hypertens Pregnancy. 2014;33:341-8.

38. Cao XL, Zhang J, Goodyer CG, et al. Bisphenol A in human placental and fetal liver tissues collected from Greater Montreal area (Quebec) during 1998-2008. Chemosphere. 2012;89:50511.

39. Edlow AG, Chen M, Smith NA, et al. Fetal bisphenol A exposure: concentration of conjugated and unconjugated bisphenol A in amniotic fluid in the second and third trimesters. Reprod Toxicol. 2012;34:1-7.

40. Chou WC, Chen JL, Lin CF, et al. Biomonitoring of bisphenol A concentrations in maternal and umbilical cord blood in regard to birth outcomes and adipokine expression: a birth cohort study in Taiwan. Environ Health. 2011;10:94.

41. Johnson PI, Sutton P, Atchley DS, et al. The navigation guideevidence-based medicine meets environmental health: systematic review of human evidence for PFOA effects on fetal growth. Environ Health Perspect. 2014;122:1028-39.

42. Stahl T, Mattern D, Brunn H. Toxicology of perfluorinated compounds. Environ Sci Eur. 2011;23:38.

43. Berg V, Nost TH, Huber S, et al. Maternal serum concentrations of per- and polyfluoroalkyl substances and their predictors in years with reduced production and use. Environ Int. 2014;69:58-66.

44. Fei C, McLaughlin JK, Lipworth L, et al. Maternal concentrations of perfluorooctanesulfonate (PFOS) and perfluorooctanoate (PFOA) and duration of breastfeeding. Scand J Work Environ Health. 2010;36:413-21.

45. Hanssen L, Dudarev AA, Huber S, et al. Partition of perfluoroalkyl substances (PFASs) in whole blood and plasma, assessed in maternal and umbilical cord samples from inhabitants of arctic Russia and Uzbekistan. Sci Total Environ. 2013;447: 430-7.

46. Jain RB. Effect of pregnancy on the levels of selected perfluoroalkyl compounds for females aged 17-39 years: data from National Health and Nutrition Examination Survey 20032008. J Toxicol Environ Heal A. 2013;76:409-21.

47. Kato K, Wong LY, Chen A, et al. Changes in serum concentrations of maternal poly- and perfluoroalkyl substances over the course of pregnancy and predictors of exposure in a multiethnic cohort of Cincinnati, Ohio pregnant women during 2003-2006. Environ Sci Technol. 2014;48:9600-8.

48. Ode A, Rylander L, Lindh CH, et al. Determinants of maternal and fetal exposure and temporal trends of perfluorinated compounds. Environ Sci Pollut Res Int. 2013;20:7970-8.
49. Kristensen SL, Ramlau-Hansen CH, Ernst E, et al. Long-term effects of prenatal exposure to perfluoroalkyl substances on female reproduction. Hum Reprod. 2013;28:3337-48.

50. Beesoon S, Webster GM, Shoeib M, et al. Isomer profiles of perfluorochemicals in matched maternal, cord, and house dust samples: manufacturing sources and transplacental transfer. Environ Health Perspect. 2011;119:1659-64.

51. von Ehrenstein OS, Fenton SE, Kato K, et al. Polyfluoroalkyl chemicals in the serum and milk of breastfeeding women. Reprod Toxicol. 2009;27:239-45.

52. Stein CR, Wolff MS, Calafat AM, et al. Comparison of polyfluoroalkyl compound concentrations in maternal serum and amniotic fluid: a pilot study. Reprod Toxicol. 2012;34:312-6.

53. Antignac JP, Veyrand B, Kadar H, et al. Occurrence of perfluorinated alkylated substances in breast milk of French women and relation with socio-demographical and clinical parameters: results of the ELFE pilot study. Chemosphere. 2013;91:802-8.

54. Barbarossa A, Masetti R, Gazzotti T, et al. Perfluoroalkyl substances in human milk: a first survey in Italy. Environ Int. 2013;51:27-30.

55. Lankova D, Lacina O, Pulkrabova J, et al. The determination of perfluoroalkyl substances, brominated flame retardants and their metabolites in human breast milk and infant formula. Talanta. 2013;117:318-25.

56. de Cock M, de Boer MR, Lamoree M, et al. First year growth in relation to prenatal exposure to endocrine disruptors - a Dutch prospective cohort study. Int $\mathrm{J}$ Environ Res Public Health. 2014;11:7001-21.

57. Needham LL, Grandjean P, Heinzow B, et al. Partition of environmental chemicals between maternal and fetal blood and tissues. Environ Sci Technol. 2011;45:1121-6.

58. Zhang T, Sun H, Lin Y, et al. Distribution of poly- and perfluoroalkyl substances in matched samples from pregnant women and carbon chain length related maternal transfer. Environ Sci Technol. 2013;47:7974-81.

59. Gutzkow KB, Haug LS, Thomsen C, et al. Placental transfer of perfluorinated compounds is selective - a Norwegian Mother and Child sub-cohort study. Int J Hyg Environ Health. 2012;215:2169 .

60. Kim S, Choi K, Ji K, et al. Trans-placental transfer of thirteen perfluorinated compounds and relations with fetal thyroid hormones. Environ Sci Technol. 2011;45:7465-72.

61. Glynn A, Berger U, Bignert A, et al. Perfluorinated alkyl acids in blood serum from primiparous women in Sweden: serial sampling during pregnancy and nursing, and temporal trends 1996-2010. Environ Sci Technol. 2012;46:9071-9.

62. Thomsen C, Haug LS, Stigum H, et al. Changes in concentrations of perfluorinated compounds, polybrominated diphenyl ethers, and polychlorinated biphenyls in Norwegian breast-milk during twelve months of lactation. Environ Sci Technol. 2010;44:95506.

63. Geyer HJ, Schramm K-W, Darnerud PO, et al. Terminal elimination half-lives of the brominated flame retardants TBBPA, HBCD, and lower brominated PBDES in humans. Organohalogen Compd. 2004;66:3820-5.

64. Zota AR, Park JS, Wang Y, et al. Polybrominated diphenyl ethers, hydroxylated polybrominated diphenyl ethers, and measures of thyroid function in second trimester pregnant women in California. Environ Sci Technol. 2011;45:7896-905.

65. Castorina R, Bradman A, Sjodin A, et al. Determinants of serum polybrominated diphenyl ether (PBDE) levels among pregnant women in the CHAMACOS cohort. Environ Sci Technol. 2011;45:6553-60.

66. Horton MK, Bousleiman S, Jones R, et al. Predictors of serum concentrations of polybrominated flame retardants among healthy 
pregnant women in an urban environment: a cross-sectional study. Environ Health. 2013;12:23

67. Carignan CC, Abdallah MA, Wu N, et al. Predictors of tetrabromobisphenol-A (TBBP-A) and hexabromocyclododecanes (HBCD) in milk from Boston mothers. Environ Sci Technol. 2012;46:12146-53.

68. Linares V, Belles M, Domingo JL. Human exposure to PBDE and critical evaluation of health hazards. Arch Toxicol. 2015;89:33556.

69. Berghuis SA, Bos AF, Sauer PJJ, et al. Developmental neurotoxicity of persistent organic pollutants: an update on childhood outcome. Arch Toxicol. 2015;89:687-709.

70. Chen A, Park JS, Linderholm L, et al. Hydroxylated polybrominated diphenyl ethers in paired maternal and cord sera. Environ Sci Technol. 2013;47:3902-8.

71. Frederiksen M, Thomsen C, Froshaug M, et al. Polybrominated diphenyl ethers in paired samples of maternal and umbilical cord blood plasma and associations with house dust in a Danish cohort. Int J Hyg Environ Health. 2010;213:233-42.

72. Zhao Y, Ruan X, Li Y, et al. Polybrominated diphenyl ethers (PBDEs) in aborted human fetuses and placental transfer during the first trimester of pregnancy. Environ Sci Technol. 2013;47: 5939-46.

73. Antignac JP, Cariou R, Zalko D, et al. Exposure assessment of French women and their newborn to brominated flame retardants: determination of tri- to deca- polybromodiphenylethers (PBDE) in maternal adipose tissue, serum, breast milk and cord serum. Environ Pollut. 2009;157:164-73.

74. Kim UJ, Oh JE. Tetrabromobisphenol A and hexabromocyclododecane flame retardants in infant-mother paired serum samples, and their relationships with thyroid hormones and environmental factors. Environ Pollut. 2014;184:193-200

75. Siddique S, Xian Q, Abdelouahab N, et al. Levels of dechlorane plus and polybrominated diphenyl ethers in two Canadian cities. Environ Int. 2012;39:50-5.

76. Ben YJ, Li XH, Yang YL, et al. Placental transfer of dechlorane plus in mother-infant pairs in an e-waste recycling area (Wenling, China). Environ Sci Technol. 2014;48:5187-93.

77. Hoffman K, Daniels JL, Stapleton HM. Urinary metabolites of organophosphate flame retardants and their variability in pregnant women. Environ Int. 2014;63:169-72.

78. Rawn DF, Gaertner DW, Weber D, et al. Hexabromocyclododecane concentrations in Canadian human fetal liver and placental tissues. Sci Total Environ. 2014;468-469:622-9.

79. Frederiksen M, Thomsen M, Vorkamp K, et al. Patterns and concentration levels of polybrominated diphenyl ethers (PBDEs) in placental tissue of women in Denmark. Chemosphere. 2009;76: 1464-9.

80. Miller MF, Chernyak SM, Domino SE, et al. Concentrations and speciation of polybrominated diphenyl ethers in human amniotic fluid. Sci Total Environ. 2012;417-418:294-8.

81. Jakobsson K, Fång J, Athanasiadou M, et al. Polybrominated diphenyl ethers in maternal serum, umbilical cord serum, colostrum, and mature breast milk. Insights from a pilot study and the literature. Environ Int. 2012;47:121-30.

82. Zota AR, Linderholm L, Park JS, et al. Temporal comparison of PBDEs, OH-PBDEs, PCBs, and OH-PCBs in the serum of second trimester pregnant women recruited from San Francisco General Hospital, California. Environ Sci Technol. 2013;47:11776-84. This study uses biomonitoring data to assess the impact of public policy changes on cumulative exposures to environmental chemicals in a population of pregnant women.

83. Wan Y, Choi K, Kim S, et al. Hydroxylated polybrominated diphenyl ethers and bisphenol $\mathrm{A}$ in pregnant women and their matching fetuses: placental transfer and potential risks. Environ Sci Technol. 2010;44:5233-9.
84. Schecter A, Colacino J, Sjodin A, et al. Partitioning of polybrominated diphenyl ethers (PBDEs) in serum and milk from the same mothers. Chemosphere. 2010;78:1279-84.

85. Agency for Toxic Substances and Disease Registry (ATSDR). Toxicological profile for polychlorinated biphenyls (PCBs). US Department of Health and Human Services. 2000. pp. 948.

86. Ogura I. Half-life of each dioxin and PCB congener in the human body. Organohalogen Compd. 2004;66:3329-37.

87. Fernandez MF, Parera J, Arrebola JP, et al. Levels of polychlorinated dibenzo-p-dioxins, dibenzofurans and dioxinlike polychlorinated biphenyls in placentas from the Spanish INMA birth cohort study. Sci Total Environ. 2012;441:49-56.

88. Cheslack-Postava K, Rantakokko PV, Hinkka-Yli-Salomaki S, et al. Maternal serum persistent organic pollutants in the Finnish Prenatal Study of Autism: A pilot study. Neurotoxicol Teratol. 2013;38:1-5.

89. Fang J, Nyberg E, Bignert A, et al. Temporal trends of polychlorinated dibenzo-p-dioxins and dibenzofurans and dioxin-like polychlorinated biphenyls in mothers' milk from Sweden, 1972-2011. Environ Int. 2013;60:224-31.

90. Boucher O, Muckle G, Jacobson JL, et al. Domain-specific effects of prenatal exposure to PCBs, mercury, and lead on infant cognition: results from the Environmental Contaminants and Child Development Study in Nunavik. Environ Health Perspect. 2014;122:310-6.

91. Veyhe AS, Hofoss D, Hansen S, et al. The Northern Norway Mother-and-Child Contaminant Cohort (MISA) Study: PCA analyses of environmental contaminants in maternal sera and dietary intake in early pregnancy. Int J Hyg Environ Health. 2015;218: 254-64.

92. Govarts E, Nieuwenhuijsen M, Schoeters G, et al. Birth weight and prenatal exposure to polychlorinated biphenyls (PCBs) and dichlorodiphenyldichloroethylene (DDE): a meta-analysis within 12 European birth cohorts. Environ Health Perspect. 2012;120: $162-70$.

93. Rodriguez-Dozal S, Riojas Rodriguez H, Hernandez-Avila M, et al. Persistent organic pollutant concentrations in first birth mothers across Mexico. J Expo Sci Environ Epid. 2012;22:60-9.

94. Veyhe AS, Nost TH, Sandanger TM, et al. Is meconium useful to predict fetal exposure to organochlorines and hydroxylated PCBs? Environ Sci Process Impacts. 2013;15:1490-500.

95. Vafeiadi M, Vrijheid M, Fthenou E, et al. Persistent organic pollutants exposure during pregnancy, maternal gestational weight gain, and birth outcomes in the mother-child cohort in Crete, Greece (RHEA study). Environ Int. 2014;64:116-23.

96. Sunyer J, Garcia-Esteban R, Alvarez M, et al. DDE in mothers' blood during pregnancy and lower respiratory tract infections in their infants. Epidemiology. 2010;21:729-35.

97. LaKind JS, Berlin CM, Sjödin A, et al. Do human milk concentrations of persistent organic chemicals really decline during lactation? Chemical concentrations during lactation and milk/serum partitioning. Environ Health Persp. 2009;117:1625-31.

98. Luzardo OP, Ruiz-Suarez N, Almeida-Gonzalez M, et al. Multiresidue method for the determination of 57 persistent organic pollutants in human milk and colostrum using a QuEChERS-based extraction procedure. Anal Bioanal Chem. 2013;405:9523-36.

99. Vigh E, Colombo A, Benfenati E, et al. Individual breast milk consumption and exposure to PCBs and PCDD/Fs in Hungarian infants: a time-course analysis of the first three months of lactation. Sci Total Environ. 2013;449:336-44.

100. Hernik A, Góralczyk K, Struciński P, et al. Polybrominated diphenel ethers, polychlorinated bipheyls, and organochlorine pesticides in human milk as markers of environmental exposure to these compounds. Ann Agric Environ Med. 2011;18:113-8.

101. Raab U, Albrecht M, Preiss U, et al. Organochlorine compounds, nitro musks and perfluorinated substances in breast milk - results 
from Bavarian Monitoring of Breast Milk 2007/8. Chemosphere. 2013;93:461-7.

102. Weldon RH, Barr DB, Trujillo C, et al. A pilot study of pesticides and PCBs in the breast milk of women residing in urban and agricultural communities of California. J Environ Monit. 2011;13:3136-44.

103. Lancz K, Murinova L, Patayova H, et al. Ratio of cord to maternal serum PCB concentrations in relation to their congener-specific physicochemical properties. Int J Hyg Environ Health. 2015;218: 91-8.

104. Vizcaino E, Grimalt JO. Maternal origin and other determinants of cord serum organochlorine compound concentrations in infants from the general population. Environ Sci Technol. 2010;44: 6488-95.

105. DiPietro JA, Davis MF, Costigan KA, et al. Fetal heart rate and motor activity associations with maternal organochlorine levels: results of an exploratory study. J Expo Sci Environ Epid. 2014;24: 474-81.

106. Gomara B, Athanasiadou M, Quintanilla-Lopez JE, et al. Polychlorinated biphenyls and their hydroxylated metabolites in placenta from Madrid mothers. Environ Sci Pollut Res Int. 2012;19:139-47.

107. Leino O, Kiviranta H, Karjalainen AK, et al. Pollutant concentrations in placenta. Food Chem Toxicol. 2013;54:59-69.

108. Virtanen HE, Koskenniemi JJ, Sundqvist E, et al. Associations between congenital cryptorchidism in newborn boys and levels of dioxins and PCBs in placenta. Int J Androl. 2012;35:283-93.

109. Daglioglu N, Akcan R, Efeoglu P, et al. Polychlorinated biphenyl and organochlorine pesticides in amniotic fluids of pregnant women in south-central Turkey. Toxicol Environ Chem. 2013;95:954 61.

110. Luzardo OP, Mahtani V, Troyano JM, et al. Determinants of organochlorine levels detectable in the amniotic fluid of women from Tenerife Island (Canary Islands, Spain). Environ Res. 2009;109:607-13.

111. Mori C, Nakamura N, Todaka E, et al. Correlation between human maternal-fetal placental transfer and molecular weight of PCB and dioxin congeners/isomers. Chemosphere. 2014;114:262-7.

112. Tsuji M, Aiko Y, Kawamoto T, et al. Polychlorinated biphenyls (PCBs) decrease the placental syncytiotrophoblast volume and increase placental growth factor (PlGF) in the placenta of normal pregnancy. Placenta. 2013;34:619-23.

113. Sexton K, Salinas JJ. Concurrent fetal exposure to multiple environmental chemicals along the U.S.-Mexico border: an exploratory study in Brownsville, Texas. Int J Environ Res Public Health. 2014;11:10165-81.

114. Patayova H, Wimmerova S, Lancz K, et al. Anthropometric, socioeconomic, and maternal health determinants of placental transfer of organochlorine compounds. Environ Sci Pollut Res Int. 2013;20:8557-66.

115. Glynn A, Larsdotter M, Aune M, et al. Changes in serum concentrations of polychlorinated biphenyls (PCBs), hydroxylated PCB metabolites and pentachlorophenol during pregnancy. Chemosphere. 2011;83:144-51.

116. Wang RY, Jain RB, Wolkin AF, et al. Serum concentrations of selected persistent organic pollutants in a sample of pregnant females and changes in their concentrations during gestation. Environ Helth Perspect. 2009;117:1244-9.

117. Wolff MS, Zeleniuch-Jacquotte A, Dubin N, et al. Risk of breast cancer and organochlorine exposure. Cancer Epidemiol Biomar Prev. 2000;9:271-7.

118. Adlard B, Davis K, Liang CL, et al. Persistent organic pollutants (POPs) and metals in primiparous women: a comparison from Canada and Mexico. Sci Total Environ. 2014;500-501:302-13.

119. Rudge CVC, Sandanger T, Rollin HB, et al. Levels of selected persistent organic pollutants in blood from delivering women in seven selected areas of São Paulo State. Brazil Environ Int. 2011:40:162-9.

120. Wohlfahrt-Veje C, Audouze K, Brunak S, et al. Polychlorinated dibenzo-p-dioxins, furans, and biphenyls (PCDDs/PCDFs and PCBs) in breast milk and early childhood growth and IGF1. Reproduction. 2014;147:391-9.

121. Schlumpf M, Kypke K, Wittassek M, et al. Exposure patterns of UV filters, fragrances, parabens, phthalates, organochlor pesticides, PBDEs, and PCBs in human milk: correlation of UV filters with use of cosmetics. Chemosphere. 2010;81:1171-83.

122. Koppen G, Den Hond E, Nelen V, et al. Organochlorine and heavy metals in newborns: results from the Flemish Environment and Health Survey (FLEHS 2002-2006). Environ Int. 2009;35: 1015-22.

123. Neta G, Goldman LR, Barr D, et al. Distribution and determinants of pesticide mixtures in cord serum using principal component analysis. Environ Sci Technol. 2010;44:5641-8.

124. Freire C, Amaya E, Fernandez MF, et al. Relationship between occupational social class and exposure to organochlorine pesticides during pregnancy. Chemosphere. 2011;83:831-8.

125. Herrero-Mercado M, Waliszewski SM, Caba M, et al. Organochlorine pesticide gradient levels among maternal adipose tissue, maternal blood serum and umbilical blood serum. B Environ Contam Tox. 2011;86:289-93.

126. Alvarado-Hernandez DL, Montero-Montoya R, Serrano-Garcia L, et al. Assessment of exposure to organochlorine pesticides and levels of DNA damage in mother-infant pairs of an agrarian community. Environ Mol Mutagen. 2013;54:99-111.

127. Garced S, Torres-Sanchez L, Cebrian ME, et al. Prenatal dichlorodiphenyldichloroethylene (DDE) exposure and child growth during the first year of life. Environ Res. 2012;113:58-62.

128. Torres-Sanchez L, Schnaas L, Rothenberg SJ, et al. Prenatal p, p DDE exposure and neurodevelopment among children 3.5-5 years of age. Environ. Health Perspect. 2013;121:263-8.

129. Elserougy S, Beshir S, Saad-Hussein A, et al. Organochlorine pesticide residues in biological compartments of healthy mothers. Toxicol Ind Health. 2013;29:441-8.

130. Waliszewski SM, Melo-Santiesteban G, Villalobos-Pietrini R, et al. Breast milk excretion kinetic of $\beta-\mathrm{HCH}, \mathrm{pp}$ 'DDE and pp'DDT. B Environ Contam Tox. 2009;83:869-73.

131. Hansen S, Nieboer E, Odland JO, et al. Levels of organochlorines and lipids across pregnancy, delivery and postpartum periods in women from northern Norway. J Environ Monit. 2010;12:212837.

132. de Tefre Renzy-Martin K, Frederiksen H, Christensen JS, et al. Current exposure of 200 pregnant Danish women to phthalates, parabens and phenols. Reproduction. 2014;147:443-53.

133. Phillipat C, Mortamais M, Chevrier C, et al. Exposure to phthalates and phenols during pregnancy and offspring size at birth. Environ Health Perspect. 2012;120:464-70.

134. Casas L, Fernandez MF, Llop S, et al. Urinary concentrations of phthalates and phenols in a population of Spanish pregnant women and children. Environ Int. 2011;37:858-66.

135. Vizcaino E, Grimalt JO, Fernandez-Somoano A, et al. Transport of persistent organic pollutants across the human placenta. Environ Int. 2014;65:107-15. This paper utilized paired placenta, maternal, and cord serum samples in a nationally representative population in Spain to measure cumulative exposures to multiple chemical classes.

136. Abdelouahab N, Langlois MF, Lavoie L, et al. Maternal and cordblood thyroid hormone levels and exposure to polybrominated diphenyl ethers and polychlorinated biphenyls during early pregnancy. Am J Epidemiol. 2013;178:701-13.

137. Carmichael SL, Herring AH, Sjodin A, et al. Hypospadias and halogenated organic pollutant levels in maternal mid-pregnancy serum samples. Chemosphere. 2010;80:641-6. 
138. Vorkamp K, Nielsen F, Kyhl HB, et al. Polybrominated diphenyl ethers and perfluoroalkyl substances in serum of pregnant women: levels, correlations, and potential health implications. Arch Environ Con Tox. 2014;67:9-20.

139. Arbuckle TE, Kubwabo C, Walker M, et al. Umbilical cord blood levels of perfluoroalkyl acids and polybrominated flame retardants. Int J Hyg Environ Health. 2013;216:184-94.

140. Lignell S, Aune M, Darnerud PO, et al. Persistent organochlorine and organobromine compounds in mother's milk from Sweden 1996-2006: compound-specific temporal trends. Environ Res. 2009; 109:760-7.

141. Croes K, Colles A, Koppen G, et al. Persistent organic pollutants (POPs) in human milk: a biomonitoring study in rural areas on Flanders (Belgium). Chemosphere. 2012;89:988-94.

142. Braun JM, Kalkbrenner AE, Just AC, et al. Gestational exposure to endocrine-disrupting chemicals and reciprocal social, repetitive, and stereotypic behaviors in 4- and 5-year-old children: the HOME study. Environ Health Perspect. 2014;122:513-20. This paper successfully assessed cumulative exposures to 52 chemicals from multiple classes in pregnant US women.

143. Park JS, She J, Holden A, et al. High postnatal exposures to polybrominated diphenyl ethers (PBDEs) and polychlorinated biphenyls (PCBs) via breast milk in California: does BDE-209 transfer to breast milk? Environ Sci Technol. 2011;45:4579-85.

144. Schuhmacher M, Kiviranta H, Ruokojarvi P, et al. Concentrations of PCDD/Fs, PCBs and PBDEs in breast milk of women from Catalonia, Spain: a follow-up study. Environ Int. 2009;35:607-13.

145. Hoepner LA, Whyatt RM, Just AC, et al. Urinary concentrations of bisphenol A in an urban minority birth cohort in New York City, prenatal through age 7 years. Environ Res. 2013;122:38-44.

146. Gascon M, Casas M, Morales E, et al. Prenatal exposure to bisphenol A and phthalates and childhood respiratory tract infections and allergy. J Allergy Clin Immun. 2015;135:370-8.

147. National Research Council. Phthalates and cumulative risk assessment: the task ahead. Washington, DC: National Academies Press; 2008.

148. Darnerud PO, Lignell S, Aune M, et al. Time trends of polybrominated diphenylether (PBDE) congeners in serum of Swedish mothers and comparisons to breast milk data. Environ Res. 2015;138:352-60.

149. Blair JD, Ikonomou MG, Kelly BC, et al. Ultra-Trace determination of phthalate ester metabolites in seawater, sediments, and biota from an urbanized marine inlet by LC/ESI-MS/MS. Environ Sci Technol. 2009;43:6262-8.

150. Rebello MT, Abas A, Nicolaides K, et al. Maternal contamination of amniotic-fluid demonstrated by DNA analysis. Prenat Diagn. 1994;14:109-12.

151. Roze E, Meijer L, Bakker A, et al. Prenatal exposure to organohalogens, including brominated flame retardants, influences motor, cognitive, and behavioral performance at school age. Environ Health Perspect. 2009;117:1953-8.
152. Arbuckle TE, Davis K, Marro L, et al. Phthalate and bisphenol A exposure among pregnant women in Canada-results from the MIREC study. Environ Int. 2014;68:55-65.

153. Braun JM, Smith KW, Williams PL, et al. Variability of urinary phthalate metabolite and bisphenol A concentrations before and during pregnancy. Environ Health Perspect. 2012;120:739-45.

154. Braun JM, Just AC, Williams PL, et al. Personal care product use and urinary phthalate metabolite and paraben concentrations during pregnancy among women from a fertility clinic. J Expo Sci Environ Epid. 2014;24:459-66.

155. Ferguson KK, Peterson KE, Lee JM, et al. Prenatal and peripubertal phthalates and bisphenol $\mathrm{A}$ in relation to sex hormones and puberty in boys. Reprod Toxicol. 2014;47:70-6.

156. Watkins DJ, Tellez-Rojo MM, Ferguson KK, et al. In utero and peripubertal exposure to phthalates and BPA in relation to female sexual maturation. Environ Res. 2014;134:233-41.

157. Weinberger B, Vetrano AM, Archer FE, et al. Effects of maternal exposure to phthalates and bisphenol A during pregnancy on gestational age. J Matern-Fetal Neo M. 2014;27:323-7.

158. Alivernini S, Battistelli CL, Turrio-Baldassarri L. Human milk as a vector and an indicator of exposure to PCBs and PBDEs: temporal trend of samples collected in Rome. B Environ Contam Tox. 2011;87:21-5.

159. Gomara B, Herrero L, Pacepavicius G, et al. Occurrence of coplanar polybrominated/chlorinated biphenyls (PXBs), polybrominated diphenyl ethers (PBDEs) and polychlorinated biphenyls (PCBs) in breast milk of women from Spain. Chemosphere. 2011;83:799-805.

160. Pratt I, Anderson W, Crowley D, et al. Brominated and fluorinated organic pollutants in the breast milk of first-time Irish mothers: is there a relationship to levels in food? Food Addit Contam A. 2013;30:1788-98.

161. Vizcaino E, Grimalt JO, Carrizo D, et al. Assessment of prenatal exposure to persistent organohalogen compounds from cord blood serum analysis in two Mediterranean populations (Valencia and Menorca). J Environ Monit. 2011;13:422-32.

162. Nanes JA, Xia Y, Dassanayake RM, et al. Selected persistent organic pollutants in human placental tissue from the United States. Chemosphere. 2014;106:20-7.

163. Brucker-Davis F, Ferrari P, Boda-Buccino M, et al. Cord blood thyroid tests in boys born with and without cryptorchidism: correlations with birth parameters and in utero xenobiotics exposure. Thyroid. 2011;21:1133-41.

164. Doucet J, Tague B, Arnold DL, et al. Persistent organic pollutant residues in human fetal liver and placenta from Greater Montreal, Quebec: a longitudinal study from 1998 through 2006. Environ Health Perspect. 2009;117:605-10.

165. Porpora MG, Lucchini R, Abballe A, et al. Placental transfer of persistent organic pollutants: a preliminary study on mothernewborn pairs. Int J Environ Res Public Health. 2013;10:699-711. 